
internationales

vol. $32-n^{\circ} 1 \mid 2016$

Les migrations des Roms roumains en Europe

\title{
Phones, Small Talk and Disputes. Transnational Communications and Community Cohesion among Roma Migrants in the Outskirts of Paris
}

Téléphones, petites conversations et disputes. Communications transnationales et cohésion communautaire chez les migrants roms en banlieue parisienne Teléfonos, chismes y conflictos. Comunicaciones transnacionales y cohesión comunitaria entre los migrantes roma en los barrios periféricos de París

\section{Norah Benarrosh-Orsoni}

\section{OpenEdition}

\section{Journals}

Electronic version

URL: https://journals.openedition.org/remi/7698

DOI: $10.4000 /$ remi.7698

ISSN: $1777-5418$

Publisher

Université de Poitiers

Printed version

Date of publication: 1 March 2016

Number of pages: 147-163

ISBN: 979-10-90426-27-6

ISSN: 0765-0752

Electronic reference

Norah Benarrosh-Orsoni, "Phones, Small Talk and Disputes. Transnational Communications and

Community Cohesion among Roma Migrants in the Outskirts of Paris", Revue européenne des migrations internationales [Online], vol. 32 - $n^{\circ} 1$ | 2016, Online since 01 March 2018, connection on 16 April 2022. URL: http://journals.openedition.org/remi/7698 ; DOI: https://doi.org/10.4000/remi.7698 


\section{Phones, Small Talk and Disputes. Transnational Communications and Community Cohesion among Roma Migrants in the Outskirts of Paris}

\section{Norah Benarrosh-Orsoni ${ }^{1}$}

Information and communication technologies (ICTs) have multiple uses and functions among migrant communities ${ }^{2}$. Digital technologies, the Internet and telephones can serve social integration in countries of destination (Diminescu, 2002) and the political struggles of undocumented immigrants (Nedelcu, 2010); they can also be used for money transfers to countries of origin (Horst, 2006). In many situations, ICTs support transnational care-giving practices between migrants and their ageing parents (Baldassar, 2007) as well as long-distance parenthood (Parreñas, 2001; Madianou, 2012). Miller (2006), building on the work of Douglas and Ney (1998), argues that the role of access to communications in measuring human welfare should be completely revised. According to Miller and those from whom he has drawn his inspiration, communication is not only a means to achieving higher incomes or a better standard of living, but also a basic human concern that needs to be valued on its own terms. This affirmation is particularly true regarding Romani sociability: rather than being real disputes, the daily, interminable and stormy conversations that animate the Roma appear as "a long and tortuous way to demonstrate that no matter what happens, the Roma always reach agreement, and speak the truth together" (Olivera, 2007: 492, my translation). As is the case in most Eastern European Roma groups, staying in the game of sociability requires one to make one's voice heard, to play and witness and to produce and receive information. Taking part in conversations, feeding gossip and meddling in conflicts is thus vital to maintaining a good position in the game.

The following descriptions and analysis revolve around the ethnography of phone communications between France and Romania and investigate how

\footnotetext{
$1 \mathrm{PhD}$ in Anthropology, Laboratoire d'Ethnologie et de Sociologie Comparative (LESC), Université Paris Ouest-Nanterre La Défense, Maison Archéologie et Ethnologie RenéGinouvès, 21 allée de I'université, 92023 Nanterre cedex ; norah.ben@gmail.com

2 This paper has been written with support from the "MigRom program: The immigration of Romanian Roma to Western Europe: Causes, effects and future engagement strategies", a project funded by the European Union under the $7^{\text {th }}$ Framework Program under the call "Dealing with diversity and cohesion: the case of the Roma in the European Union" (GA319901).
} 
Roma migrants transform their specific verbal interactions as they firmly settle in different countries across Europe. When they became affordable, international phone calls completely transformed the structure of long-distance relationships, enabling the development of transnational routines among separated groups of kin, and maintaining the closeness of the whole migrant community. In order to highlight the role played by these communications devices and their consequences for transnational family life of Roma migrants, I relied on the rich theoretical background provided by material culture and consumption studies ${ }^{3}$. Indeed, this research aims to underline the pertinence of investigating migrant practices through their material entanglements and show how this lens can shed new light on their shifting social constructions. I would like to highlight the role and agentivity of material supports in the structuration of migrant families. By providing a feeling of immediacy and virtual intimacy, ICTs in particular accelerate the emergence of a "culture of migration", defined by Massey et al. (1994) as common values and aspirations shared by those who have experienced life abroad. More specifically, the daily use of ICTs enables migrants to transcend the traditional continuity that many of them build between their places of origin and destination (Diminescu, 2005), favouring instead a collective search for ubiquity. I start by providing a general overview of the recent evolutions undergone by phone operators targeting migrants over the last few years. I then analyze the main types of communications aimed respectively at building a long-distance routine, reminding the migrant of his duties, and maintaining conflicts. Finally, I examine how disputes and interferences act as a common good that individuals seize to maintain their place in the community and reinforce social cohesion.

Most first-generation migrants maintain strong roots in and commitments to their homeland when they have the capacity to do so. The flows of material goods, money, information or ideas between the country of origin and the country of migration have an essential role in this attempt. In both directions, means of transportation carry all kinds of consumption goods, commodities and parcels that people send to their relatives. Information, gossip and ideas travel through the passengers themselves, or are virtually conveyed through ICTs. These technologies, along with many other material supports, contribute to the production of a virtual co-presence and foster the invention of a transnational family life.

In the last twenty years, many qualitative studies have shown the extent to which the material environment and, in particular, real estate investments in the homeland, is the most favored medium for expressing one's migratory success (De Villanova et al., 1994; Fletcher, 1999; Moisa, 2011; Boccagni, 2013; Lopez, 2015). Although a crucial aspect of any migratory journey, the materiality of migration has received little attention (Basu and Coleman, 2008). Material experiences sometimes require tricky adjustments, whether in terms of what people carry with them (Burrell, 2008), transportation means (de Tapia, 2004; Faret, 2004; Brachet, 2007), or the manner in which home and housing practices are conceived and transformed (Rapport and Dawson, 1998; Frykman, 2009; Rosales, 2010). Mobile lifestyles, such as that of this Romani group have experienced for many years, indeed rely on a great variety of technical and techno-

3 Such as Miller (1995), Warnier (1999), Kaufmann (2011) and Noble (2004). 
logical means. Combined with the flows of material goods circulating between the countries of origin and destination, they represent the most important tools of a transnational social life. These material tools are essential to permanently connect distant places and people. In so doing, migrant individuals ensure social cohesion within their communities and, as we will see, sustain the emergence of a shared sense of double-rootedness. The feeling of being equally attached to several locations, which is common to many migrants, is usually objectified not only in sets of practices and habits but also in the material and symbolic domestication of familiar places. In our case, Roma migrants maintained special relations with both their places of origin and their places of migration, which represented the two main poles of a migratory space they carefully maintained.

The generalization of migration and its related practices also transformed Romani households which had to adjust to new lifestyles and became transnational households. This particular family set-up can be defined as follows: a transnational household is composed of family members who would share the same roof if they lived in the same place, and who continue to take care of each other even though they are scattered between home and migration countries ${ }^{4}$. The Roma families in this study are settled in France but many of their close and distant relatives have migrated to other Western European countries. They have all maintained intense relationships with their peers across Europe, as well as with their home villages and their "left-behind" parents. These relationships and communications are therefore part of a strong transnational social life, even though each Roma migrant may only physically circulate between his places of origin and settlement. Transnational migration, and more broadly, transnationalism refer to the "ongoing and continuous way in which current-day immigrants construct and reconstitute their simultaneous embeddedness in more than one society" (Glick Schiller et al., 1995: 48). Although the concept has received severe criticism within the field of migration studies ${ }^{5}$, it is still relevant for describing the variety of links that migrants build between their main places of attachment, and for analyzing these complex processes at a micro level.

\section{Methodological Frame and Elements of Context}

This research began in 2006 and ended in 2012 in the town of Montreuil (Paris) where my fieldwork comprised informal and participant ethnography in the many squats and caravans where the Roma live. During weekly and sometimes daily visits, I became intimate with many women and their families and rapidly learnt to speak Romanès. I spent innumerable hours drinking strong coffee, watching and commenting on soap operas, and listening to their accounts of never-ending family dramas. I also accompanied the families to their Pentecostal church and participated in their shopping expeditions to town. In 2008, 2010 and 2011, I stayed in two of their Romanian villages where my four months of intense fieldwork consisted of the same activities and communitarian busi-

\footnotetext{
4 For a complete ethnography of the Romani transnational household, see my doctoral dissertation (Benarrosh-Orsoni, 2015a).

5 See Portes (2001), Waldinger and Fitzgerald (2004), Glick Schiller and Levitt (2006). More recently, Waldinger (2015) submitted the concept of "cross-border connections" which, according to the author, should make it possible to better situate migrants' activities and sense of belonging between States, and not beyond them.
} 
nesses. These trips to Romania and back were an opportunity to document their journeys across Europe and investigate the micro-society existing on the road 6 : Roma migrants travel between Montreuil and their home village in a nine-seat microbus owned and driven by Romanian citizens who have succeeded in converting their migration path into a fruitful business. Over the course of these six years, I conducted only a few recorded interviews as appropriate occasions rarely presented themselves. Most of the time, my attempts were not taken seriously or those interviewed were too embarrassed by these unusually formal and serious interactions to focus on my questions.

Members of the Romani community I studied come from several villages in the Arad area in the West of Romania, near the Hungarian border. They recognize each other as equals, as belonging to the same "nation" or "race" as they say in Romanès. Parents often like to marry off their children to members of the group with whom they share common cultural and religious values, economic practices, and judgments about other Roma groups. Many Roma began settling in the outskirts of Paris in the early 2000s. Each year, they settled and built personal networks embracing other Roma or locals and found all kinds of formal and informal work opportunities. For the first six years, they lived in squats from which they were often evicted. In 2008, the families were rehoused in caravans located across several temporary sites where they lived for six years, until most of them gained access to social housing ${ }^{7}$. In spite of several political conflicts and the malfunctions that punctuated the rehousing program ${ }^{8}$, the Roma were kept away from many forms of precariousness affecting other migrants. They no longer feared evictions, nor did they risk deportation to Romania, and beggars, scrap-iron dealers and informal traders were somewhat protected from legal troubles. These families are now deeply rooted in Montreuil and consider themselves locals: just as they regularly "go back home" to their Romanian villages, travelling back to Montreuil also means coming home, as the town has become essential to their identity. This is indeed where they spend most of the year, and their home villages have turned into holiday resorts that "eat up" their yearlong savings in just a few weeks. Summer in Romania is a time for family reunions and construction work during which everyone must build, renovate or redecorate his/her house according to the latest trends.

\section{The Roma and their Phones}

\section{Ethnic Business}

In France as in other Western countries, a specific ethnic business has developed within the mobile phone market targeting immigrants seeking to call their home countries. Many of them cannot afford normal phone plans which

\footnotetext{
6 Their transportation system has been analyzed in Benarrosh-Orsoni (2015b). For community-based transportation, see also Valenzuela et al. (2005).

7 For a complete analysis of the Montreuil rehousing program, see Benarrosh-Orsoni (2011). 8 The program, initiated by the Green Party recently elected to the town council, offered housing and social and administrative support to a precarious and foreign population. Montreuil is located in the department of Seine-Saint-Denis, a territory affected by serious poverty and interminable waiting lists for social housing seekers. In this context, many locals saw the Roma as newcomers unworthy of benefiting from municipal hospitality.
} 
are often expensive and require them to have a regular address, a bank account, etc. Migrants therefore literally "chase" any cheap opportunity to communicate abroad that might satisfy their need for proximity (Diminescu, 2005). Several mobile phone operators have specialized in ethnic marketing and launched an "advertisement war" to control this market. Targeting ethnic food stores, small phone shops and Internet cafes, they have also begun to chase after migrant clients, promising them the most suitable offers aligned to their way of communicating. Like other precarious migrants, Romanian Roma have become accustomed to "juggling with different operators, often having two, three, or even more SIM cards, for special offers" (Belouezzane and Ducourtieux, 2012). Phone numbers change regularly and the SIM card turnover is unceasing.

In parallel, French landline operators have developed "global" offers which have also deeply transformed the communication opportunities across several countries. These offers include a landline, Internet and television plan. Quite recently, many operators have expanded their offers to include unlimited calls to landlines in a large number of countries. The few Roma families who had succeeded in moving into apartments in Montreuil quickly signed up for these offers in order to benefit from the different advantages, especially the free calls to Romanian landlines. As a consequence, there was a rapid emergence of landlines in some of the Romanian village houses where there had been done before. Romania's situation in this regard is quite similar to many other developing countries which have witnessed an explosion of mobile telephony since its inception, but where landlines, considered a luxury, have until recently been nonexistent among low-income households (Madianou and Miller, 2011). Broadly speaking, "the costs of building infrastructure are far more conducive to wireless over wired phones" (Vertovec, 2004: 222), resulting in many more mobile than landline phones in developing countries. Consequently, although rural Romanians had been using mobile phones since the late 1990s, it was not until 2010 or so that they were able to equip their houses with landline phones. These spread even more rapidly a few years ago when Romanian operators responded by developing the same kind of phone plans as those in Western countries.

\section{Romani Call Centers}

By 2011, several Roma households had equipped their homes with landlines that gave them access to television and the Internet for ten euros per month, but they were mainly used to receive calls from France. Naturally, the majority of Roma living in caravans in Montreuil had no landlines but one only needed a cousin or distant relative settled in an apartment. These apartments became sites of frequent meetings during which everyone made free calls to their parents, children or brothers who had remained behind temporarily in the village. Among the few Romanian homes with a landline in France, I observed the same daily meetings around the phone where next of kin and neighbors received calls from France, Belgium or Ireland. Living rooms were quickly transferred into "call centers" organized according to lineage and affinities. Everyone knew from where he/she could hear from his/her family, as everyone in Montreuil knew the number to dial to reach his/her parents at a friendly neighbor's house who, quite often, was also a cousin. In Romania, however, the landline is only used to receive calls. Nobody dares pick up the phone and dial a number, fearing exorbitant phone bills. 
The first and primary impact of introducing a new medium in a group is not necessarily the sudden emergence of new needs; rather, "the tendency is to seize upon it in order to finally realize some desire that was already present, but so far has been frustrated, because people didn't have the means to fulfill it" (Miller, 2010: 115). There is every reason to believe that this was also the case of intense local and international communications among the Roma: although the introduction of landlines significantly increased the frequency of international communications among kin, they had long mastered the art of quarrelling and endless debates. Simultaneously, new communication possibilities unsurprisingly gave rise to new inventions and practices. Thanks to landlines, spending entire evenings on the phone is now common.

In Irina's village house, the new phone rings constantly. It is often her daughter Diana, calling either from the apartment of her uncle who recently moved into social housing in Montreuil, or from her sister's apartment nearby. One night, Diana went to her uncle's house with several of her cousins whose parents also live in Romania. As soon as the landline rang at Irina's, we quickly ran to the neighbors to tell George and Zorita that their elder daughters were on the phone. They ran up to Irina's with their younger children who were staying with them. On each side of the phone, the loudspeaker was on, as is always the case, and each one wanted to say a few words to everyone and ask the very same questions. Since phones' appearance in Romanian houses, everyone listens out for their ring because it always means that somebody is calling from abroad, and no one would miss such a call.

\section{Scenes of Communication}

In Romania, calls within the country are never made via landlines but, rather, via the widespread cellphones. With the rapid development and intense competition in the Romanian cell phone market, national calls on the same network are very cheap, allowing users to stay on the phone for hours. Some Romanians even have two cellphones, one for each of the two main operators, and they use them depending on their interlocutor's operator. Everyone takes advantage of this cheap communication opportunity by multiplying calls to other villages or even to close neighbors in collective and loud conversations. During the winter, people spend entire days indoors. As Diana and her sister sew, they call here and there, but mostly they call their elder brother who lives in another village close by. They call him several times a day and quite often, the conversations are similar. He is kept informed of every domestic detail, gives his opinion and asks questions, and wants to be told once again what so-and-so said. But communicating can be a tricky affair. In 2010, the mobile network coverage in the village was far from perfect. Obtaining a network signal required a geographical mastery of the house. The best solution was often to balance the cell phone on the edge of the bed. Once the loudspeaker was on, everyone in the room would gather around the phone, taking care not to touch or move it. During these recurrent collective phone calls, people participated from across the room and were sometimes forced to shout to be heard by the caller. Jokes were successively told and were followed by laughter. The little device on the bed drew everybody's attention and, for hours on end, the elder brother became part of the household. The sisters also called their cousins, cooped up in their neighbors' houses. When extreme temperatures or snow kept them from visiting 
each other, the cell phone was the best way to spend time together, to find out what their neighbor was eating and which TV program he/she was watching in order that they might watch it together. As Diana said, making calls helped "pass the time". And when she did not know whom to call, she played pranks, dialing random numbers and pretending to be looking for someone.

In the Roma communication landscape, no one mentioned the use of the Internet, emails or Skype to communicate with their family. They did, however, use YouTube intensively by using their cell phones to post short videos recounting community events. While migrants of different nationalities across the world seem to have rapidly become familiar with Internet technology to communicate with their kin abroad (Wilding, 2006), the Romanian Roma in France are not yet among them. This may be related to the remoteness of the Romanian village in which Internet access seems to have been quite recent and remittances are hardly ever invested in improving the technological comfort of the house. It may also be related to the precarious housing conditions the Roma have faced until now, moving from squatted houses to overcrowded caravans where Internet connections have never been possible? .

Until recently, people living far from the village had to spend their precious money, once or twice a week, to maintain relationships with the village by calling their family from mobile phones or using pre-paid telephone cards which remained very expensive. Surprisingly enough, the modernity of kin work (di Leonardo, 1987) at a distance seems to have matched the emergence of landlines on both sides touched by migration. While national calls in Romania were already affordable through mobile phones, international phone calls became a common practice when landline phones spread first in France, then in Romanian villages, allowing migrants "to communicate with their families abroad on a regular, if not day-to-day basis. [...] The communications allowed by cheap telephone calls serve as a kind of social glue connecting small-scale social formations across the globe" (Vertovec, 2004: 220). I would now like to explore the various characteristics of these calls in order to understand the shape taken by this "social glue" in the frequent international phone calls.

\section{Different Kinds of Calls}

\section{Connecting and Reminding Migrants of their Duties}

Often, at night, the whole family gathers in the living room, watching the musical evening programs that do not require any particular attention. Cornel, the father, lies on the bed while his wife Irina finishes cleaning up in the kitchen. On the landline speaker, they listen to Rudica, their elder daughter who lives in Montreuil, giving the latest news of her family. On either side, people talk to each other, watch television while yawning, or even leave the room. No one is in a hurry; they simply wait for the next topic of conversation. When there is nothing more to add, they repeat the same things innumerable times, and it is important for them to keep on repeating them. These practices show that these conversa-

9 In 2015, all the families were finally rehoused in standard social housing. To be documented and fully understood, the recent uses of more diversified digital communication tools deserve further investigation. 
tions often have a "phatic" function (Jakobson, 1963) in the broad sense, and that their purpose is to establish a connection and maintain a link, rather than to communicate a particular content. These light conversations occur in every Roma household and are the real cement of the "virtual intimacy" (Wilding, 2006) everyone seems to be seeking. This confirms that for most migrants and their kin, who are longing for each other, "more significant than what is said in these exchanges is the moment of exchange itself, which reinforces a sense of the relationship between sender and receiver" (Wilding, 2006: 132). Members of the Roma families maintain a "connected presence" (Licoppe, 2004) by chatting on their free landline calls. Aided by a rather old technology, the Roma manage to create a shared banality and a daily transnational routine that makes them feel close to each other in spite of the distance, just as others do nowadays thanks to the many mobile communication devices available (Licoppe and Smoreda, 2005; Ling, 2007).

Another dimension of communications in transnational families concerns the duties of migrants toward their left-behind relatives. Zorita came to Irina's to speak to her elder daughter and one of her sons, calling from Montreuil. She asked her son how business had been since she left, and ended the conversation by saying: "Make money, so that we don't starve here! [keren lové, te na meras bokhatar kathé!]". Her younger daughter, a permanent resident of the village, needed diapers and milk, and the gas cylinder was empty.

Irina's daughter Diana, who went back to Montreuil several months ago also called her mother daily. Staying alone in her new apartment was boring, which is why she called her parents several times a day. On one of these calls, her sister Cristina who lived in the village began to lecture her: why did she not make better use of her free time while the kids were at school? Why could she not go "to the supermarket, sit at the entrance and beg?" She told her to go there now and again tomorrow, as everyone knew that so-and-so had made good money begging there! Meanwhile, in the village, there was insufficient money available to continue with the work on her house, and yet she sent no money as she was making none. But Diana did not want to go begging; she was waiting for her temporary residency permit which would allow her to look for "a real job".

Sayad (1985) writes about "ordinary messages", each of which simply seems to remind others of what they already know in order to maintain a connection. Although these ordinary messages give the impression that nothing important is said, they often have a wider function. They usually end up "reminding the migrant of his obligations toward his family - for it is almost always what it's about - and to insist that he fulfills them, making him feel guilty, and becoming a kind of censor; these are the functions that only the verbal message, in its most perfect form, can fill" (Sayad, 1985: 62).

The parents back home try to remind the absent migrant that he is still, first and foremost, a member of the family group, especially when he's far away, sometimes alone, or building a completely different kind of life from the communitarian one, as was sometimes the case with Sayad's Algerian immigrants. Between the lines, the migrant understands that each message is meant to remind him of his duties as a member of the group. If we follow Miller's argument (2006), for many low-income individuals, wages or business earnings 
do not matter as they are negligible. What really matters is the help they receive from others, from "those who have it", in or outside the country. We can reasonably argue that this also applies to these Roma since, during the periods spent in the village, income is virtually non-existent. Everyone counts on the financial, material and food support sent by relatives from abroad. Back in Montreuil, the first concern of those who left their kin behind is thus to prepare an emergency food parcel (pacheto in Romanès) to be sent straightaway on the next microbus heading to Romania. Most households regularly send parcels whose economic function is evident to the village. These parcels usually contain basic and nonperishable food products easily and cheaply found in urban French discount supermarkets; they are intended to spare the Roma villagers from shopping in the small and expensive village stores. Food parcels are often accompanied by remittances entrusted to a bus passenger and by all kinds of commodities the Roma buy or find in the streets - pieces of furniture, clothes, ornaments and figurines for sideboard windows. Parcels are among the recurrent phone call topics between Montreuil and the village and also among those who stay in the village on a permanent or temporary basis. People talk about what they have just received, about what they expect in the next pacheto, or about what their children cannot afford to buy and send to them from France. The elderly Roma who never leave the village persistently mention what they really need or would like to receive during phone conversations with their kin. In so doing, they maintain an underlying but clearly expressed pressure on their children who must, in turn, repeatedly swear they will not let their poor parents starve.

Sending remittances to the home country is a well-known obligation for economic migrants and a burden for newly arrived or low-income migrants (Horst, 2006; Riak Akuei, 2005). For the Roma of this group, sending a pacheto, some money and anything else they can find to the village as soon as they arrive in France, and afterwards on regular basis, is a familial duty that most of them seem to accept. Is it less of a burden for them than for other migrants? Other than the fact that these migrants are far less in need than the Sudanese refugees described by Riak Akuei (2005), several factors explain why the parcel and remittances traffic is smoother between France and Romania. First, in this familial migration, members of one family are more numerous in France than in the village, allowing them to share their material responsibilities towards their aged and young kinfolk back home. Second, over the course of their migration, most of them have switched roles, alternating longer stays in France with shorter ones in Romania. Everyone has thus found him/herself, at least once, in the position of parcel sender and receiver. This long-term shared experience has taught them how much everyone depends on financial and material remittances to face the costs of daily life in Romania. In the event of anyone taking too long to send the much-awaited parcels, the phone is the best way of transmitting an animated oral request to accelerate the process. A rather effective means of maintaining pressure for financial support, phones are now at the heart of the economic survival of such migrant households (Miller, 2006).

\section{Conflicts and Interferences}

For a group whose members are scattered in different countries, there are several ways in which social cohesion and strong ties can be maintained. Phone calls enable people to share a daily routine. They can also be a means through 
which younger migrants are reminded of their support duties. I will now turn to how maintaining high levels of conflict and disputes is another effective way of preserving dense interpersonal relationships.

The story of Moïse's departure is above all a story of child fostering ${ }^{10}$. Old Irina says she loves Moïse more than any of her other grandchildren because she's the one who raised him. Her eldest daughter left Moïse in her care when he was just a newborn. At the time, their living conditions - in some wasteland in one of the Parisian suburbs - were too precarious for a baby. Moïse stayed with his grandparents and his aunt Cristina for four years. His mother then took over and he did not go back to the village for several years. Irina said that when she saw him again in 2009, "that was it, he was all grown up!" A dispute broke out at the end of Moïse and his parents' last visit to the village. As they were about to leave, the child refused to get into the car and hid in the closet, repeating that he wanted to "stay home". His mother got angry and began to threaten him with a wooden spoon. They were quite in a hurry; the father had to report for work in Paris the next day and could not risk his job. However, he left the burden of negotiations to his wife and waited outside for the crisis to come to an end. The tension increased when Irina and Cristina begged the mother to leave the child with them. For the parents, this was not an option: "What would I say to his teacher? That he's sick? Would I lie to him? You can be sick for two weeks, but what will I say then? He must go to school, otherwise they won't rehouse us when they tear down the site", the father argued. Suddenly, all the women started yelling at each other: The mother telling the child to get in the car; the grandmother and the aunt, both in tears, imploring that he should stay with them. And as the car finally left with everyone on board, Cristina started tearing her hair out and cursing her sister. Afterwards, she took refuge in her bed and stayed there all day, lying mute and strumming on her cellphone. That same evening, several neighbors came by, asking for details about the dispute they had heard in the morning but could not see well enough from their doorsteps, probably not daring to come any closer. Mother and daughter repeatedly narrated to the curious neighbors each of the protagonists' actions and words. Meanwhile, the landline kept ringing and even before Moïse and his parents reached Paris, everyone living there knew about the memorable fight in the village. The next day, Irina had a long argument with her two other daughters living in Montreuil. Cristina, still deeply upset, refused to come and talk to them. Later, yet another cousin called from Montreuil asking to be told every detail of the dispute in order that she might offer an informed opinion.

As is the case with other migrant populations, ICTs seem to be of little use in supporting inter-individual ties among Roma families, (Baldassar, 2008; Horst, 2006). Rather, they are used for collective practices of communication. This can be explained by the fact that, in general, very few individualistic concerns, claims or needs exist within Roma houses. Any urgent business affecting a few residents -

10 Child fostering is widespread among these Roma families. It mostly happens when a woman remarries after a first failed marriage and her new husband refuses to raise her first child. These children are very often "taken" by their grandparents, who will raise them as their own. Moïse's story, however, is not representative of the many existing fostering cases among the Roma which are often definitive. Although temporary fostering is also common, it does not last and most cases remain invisible: the child often goes back to live with his/her parents when their situation improves. 
during the day or at night - immediately becomes the business of the whole household. This leaves very little room for intimacy, quietness or loneliness and reveals the odd manner in which individuals are perceived, suggesting that their place depends on their participation in the activities and concerns of the whole group. While many consider the house to be the best place in which to rest and shut oneself away from social pressure (De Certeau et al., 1994: 207), this does not reflect the reality of the Roma house and daily life at all. In both the French caravans and village houses, no wall or doors that remain unlocked can shield residents from the ongoing turmoil of the community. In other words, there is little room for the individual in a world in which loneliness is always considered a burden and solitary pastimes are non-existent. As is the case among French Manouches, intimacy is something the Roma people share: children are raised together, sleep together, and become adults without ever having been lonely (Poueyto, 2011: 77). In these holistic societies, each person's singularity does not make him or her an individual as we traditionally understand it (Le Breton, 1990: 29). Moreover, singularity is "of a quite recent appearance in the history of the western world" (Le Breton, 1990: 19). In the Roma house, everyone is first a member of a greater collective body whose concerns, interests and physiological and communicational needs always echo as one.

Whether to initiate, sustain or resolve conflicts - by phone or in person the Roma often mention facts, gestures or words spoken elsewhere. In many households, the youngest son lives in his parents' house with his wife and the unmarried members of the family. His mother watches over this little world and coordinates the home life. Young single women and the daughter-in-law share domestic chores and care for children and elders. The integration of a young wife into her husband's household can be tricky and success mainly depends on her efforts to satisfy her mother-in-law and build a strong relationship with her sisters-in-law. But even in families where women live in harmony, conflicts may erupt because of challenging housework rhythms. During her stay in the village, and in order to convince her mother-in-law that her own daughter had become unbearable, one of these daughters-in-law invoked a long list of incidents that occurred while the two young women were in Montreuil. She narrated many anecdotes involving residents of caravans: according to her, each of them had experienced trouble with her sister-in-law. Conflicts in the village often crystallize around events that arose in Montreuil. Similarly, many fights in Montreuil are caused by disputes which took place in the village. The common geographical origin of these Roma who live together all year long in Montreuil has probably much to do with their constant need to connect these two places through gossip, conflict and all forms of hostility.

More generally, the fueling of conflict seems to arise from the need to be involved in events that occur when they are away. It enables everyone to influence all situations, both nearby and remote. When Irina's cousin calls her from Montreuil asking about Moïse's departure, she gathers all the elements in order to be able to relate the event in Montreuil and possibly meddle in the child's parents' lives. Similarly, Irina and her daughter Cristina discuss, on a daily basis, Diana's life in Montreuil. Diana, in turn, asks every evening about the work carried out in the house she recently bought in the village. Her mother Irina has just finished working on the plaster friezes adorning the walls of the living room; she is yet to paint them gold. Tomorrow they will paint the rusty balustrade on 
the balcony but they still have to pay the workers who will lay the tiles. Diana promises to send some money soon but strictly forbids them from spending it on anything other than her house. When she asks for general news, they spare no details about the latest rumor of their young neighbor's marriage.

Whether it is about anecdotal matters or a serious crisis, all members of the close and extended family are keen to take part in these discussions. Even when they are not asked to, they spontaneously get involved, calling to interfere, to give their opinion and arbitrate. Stories heard on the phone turn into material for sociability on the front steps of houses and caravans. Both in Montreuil and in the village, any event is quickly released to serve as a common good that people seize and keep alive wherever they are. Because they generously fuel the contemporary history of their group, conflicts in particular play a key role in maintaining relationships and social cohesion.

\section{Conclusion}

In this paper, I have highlighted how phone communications affect family life and serve community cohesion. Topics that feed collective sociability seep into family exchanges during the long night calls, but the art of private strife is also fed by the many friends and neighbors who seize such opportunities to enhance the group's affairs. Landlines, for the time being, serve a single purpose: in the village they make it possible to receive calls from abroad; in Montreuil, they are primarily used to call Romania. Cellphones, however, are often the only tools available for handling a wide range of media. These small devices which have integrated the capabilities of computers and cameras can emit and receive calls and record collective or religious events which are then uploaded on YouTube and Facebook. They are also used to watch and share sermons and popular religious songs from the playlist of young and fashionable Pentecostal individuals. The manner in which Romanian migrants use their phones and other digital tools form what Madianou and Miller (2011) refer to as "communication ecology" consisting of many complementary technological channels.

Maintaining inter-personal ties is the first desire expressed by migrants separated from their loved ones. However, as soon as the need for closeness is satisfied, it is overtaken by the most diverse forms of sharing that people invent. With the development of communication options, many changes have been introduced into migrants' lives, and the classic opposition between presence and absence needs to be revised. As I have demonstrated here, the members of this migrant community have gone beyond the expected wish of continuity and have developed "ubiquitous systems of social interaction at a distance" (Nedelcu, 2010: 48) through daily interactions with a variety of material tools and supports. Roma migrants and their left-behind relatives have developed new perceptions of distance, time and spaces that have modified the meaning of presence and absence. The existence of such streams and technical supports has allowed them to consolidate their double-rootedness in both places, maintaining strong ties and carrying on as a single group in spite of their geographical dispersal. 
It is worth mentioning that the establishment of free movement within the European Union has had a huge impact on contemporary migration practices. Following this new order in particular, the Roma and their fellow European migrants can think of themselves as being both "here" and "there." More than physical circulations, it is sometimes the very possibility of traveling that better embodies this spatial dualism. Those who do not travel keep their family and community commitments alive through phone communications and performative discourses. These speeches incorporate individual statements of belonging and loyalty to the village within a collective reality. The various situations exposed in this paper highlight that international mobility and multiple spatial references do not necessary lead to uprooting. By exploring phone communications, we have shown the extent to which the circulation of intimacy, information and conflict connects scattered individuals and reinforces their respective special attachments.

\section{References}

Baldassar Loretta (2008) Missing Kin and Longing to be Together: Emotions and the Construction of Co-presence in Transnational Relationships, Journal of Ethnic and Migration Studies, 29 (3), pp. 247-266.

Baldassar Loretta (2007) Transnational families and aged care: The mobility of care and the migrancy of ageing, Journal of Ethnic and Migration Studies, 33 (2), pp. 275-297.

Basu Paul and Coleman Simon (2008) Migrant worlds, material cultures, Mobilities, 3 (3), pp. 313-330.

Belouezzane Sarah et Ducourtieux Cécile (2012) À Barbès, la bataille de la carte SIM " ethnique " fait rage, Le Monde, 12 juin.

Benarrosh-Orsoni Norah (2015a) Des maisonnées transnationales. Une migration rom dans ses routes, lieux et objets entre la Roumanie et la France, Thèse en anthropologie, Université Paris Ouest-Nanterre La Défense.

Benarrosh-Orsoni Norah (2015b) Prendre la route à bord du microbus. Mobilités, ancrages et territorialité chez des Roms roumains entre Arad et Montreuil, in Michèle Baussant, Irène Dos Santos, Evelyne Ribert et Isabelle Rivoal Éds., Migrations humaines et mises en récit mémorielles. Approches croisées en anthropologie et préhistoire, Paris, Presses Universitaires de Paris Ouest, pp. 295-324.

Benarrosh-Orsoni Norah (2011) Bricoler I'hospitalité publique : réflexions autour du relogement des Roms roumains à Montreuil, Géocarrefour, 86 (1), pp. 55-65.

Boccagni Paolo (2013) What's in a (migrant) house? Changing domestic spaces, the negociation of belonging and home-making in Ecuadorian migration, Housing, Theory and Society, 31 (3), pp. 277-293.

Brachet Julien (2007) Un désert cosmopolite. Migration de transit dans la région d'Agadez (Sahara Nigérien), Thèse, Université Paris Panthéon Sorbonne.

Burrell Kathy (2008) Managing, Learning and Sending: The Material Lives and Journeys of Polish Women in Britain, Journal of Material Culture, 13 (1), pp. 63-83. 
De Certeau Michel, Giard Luce et Mayol Pierre (1994) L'invention du quotidien. Tome 2 : Habiter, cuisiner, Paris, Folio, 448 p.

De Villanova Roselyne, Leite Carolina et Raposo Isabel (1994) Maisons de rêve au Portugal, Paris, Creaphis, 224 p.

Diminescu Dana (2005) Le migrant connecté. Pour un manifeste épistémologique, Migrations Société, 17 (102), pp. 275-292.

Diminescu Dana (2002) L'usage du téléphone portable par les migrants en situation précaire, Hommes et Migrations, 1240, pp. 66-79.

Douglas Massey and Ney Steven (1998) Missing persons. A critique of personhood in the social sciences, Berkeley, University of California Press, 223 p.

Faret Laurent (2004) Pratiques de mobilité, transport et acteurs transnationaux dans le champ migratoire Mexique-États-Unis, Autrepart, 32 (4), pp. 149-167.

Fletcher Peri (1999) La casa de mis sueños, Boulder, Westview Press, 184 p.

Frykman Maja (2009) Material aspects of transnational social fields: An introduction, Two Homelands, 29, pp. 105-113.

Glick Schiller Nina, Basch Szanton and Blanc Cristina (1995) From immigrant to transmigrant: Theorizing transnational M-migration, Anthropological Quarterly, 68 (1), pp. 48-63.

Glick Schiller Nina and Levitt Peggy (2006) Haven't we heard this somewhere before? A substantive view of transnational migration studies by way of a reply to Waldinger and Fitzgerald, The Center for Migration and Development, Working Paper Series, \#06-01, Princeton University.

Horst Heather (2006) The blessings and burdens of communication: Cell phones in Jamaican transnational social fields, Global Networks, 5 (2), pp. 143-159.

Horst Heather and Miller Daniel (2005) From Kinship to Link-up: Cell Phones and Social Networking in Jamaica, Current Anthropology, 46 (5), pp. 755-778.

J̦akobson Roman (1963) Essais de linguistique générale (Tomes 1 et 2), Paris, Éditions de Minuit, 260 p.

Kaufmann Jean-Claude (2011 [1997]) Le cœur à l'ouvrage, Paris, Nathan, 380 p.

Le Breton David (1990) Anthropologie du corps et modernité, Paris, PUF, 330 p.

Leonardo Micaela (di) (1987) The female world of cards and holidays: Women, families, and the work of kinship, Signs, 12 (3), pp. 440-453.

Levitt Peggy and Glick-Schiller Nina (2004) Conceptualizing simultaneity: A transnational social field perspective on society, International Migration Review, $38(3)$, pp. 1002-1039.

Licoppe Christian (2004) Connected presence:The emergence of a new repertoire for managing social relationships in a changing communications technoscape, Environment and planning D: Society and space, 22, pp. 135-156.

Licoppe Christian and Smoreda Zbigniew (2005) Are social networks technologically embedded? How networks are changing today with changes in communication technology, Social Networks, 27 (4), pp. 317-335. 
Ling Rich (2007) Mobile communication and mediated ritual, in Kristóf Nyiri Ed., Communications in the $21^{\text {st }}$ century, Budapest, Hungary.

Lopez Sarah (2015) The remittance landscape. Spaces of migration in rural Mexico and urban USA, Chicago and London, University of Chicago Press, 315 p.

Ma Mung Emmanuel (1999) La dispersion comme ressource, Culture \& Conflits, 33-34, pp. 89-103.

Madianou Mirca (2012) Migration and the accentuated ambivalence of motherhood:The role of ICTs in Filipino transnational families, Global Networks, 12 (3), pp. 277-295.

Madianou Mirca and Miller Daniel (2011) Mobile phone parenting: Reconfiguring relationships between Filipina migrant mothers and their left-behind children, New Media and Society, 13 (3), pp. 457-470.

Massey Douglas, Goldring Luin and Durand Jorge (1994) Continuities in transnational migration: An analysis of nineteen Mexican Communities, American Journal of Sociology, 99 (6), pp. 1492-1533.

Miller Daniel (2010) Stuff, Cambridge, Polity Press, 169 p.

Miller Daniel (2006) The Unpredictable Mobile Phone, BT Technology Journal, 24 (3), pp. 41-48.

Miller Daniel (1995) Consumption as the vanguard of history: A polemic by way of introduction, in Daniel Miller Ed., Acknowledging consumption: A review of new studies, New York and London, Routeledge, pp. 1-57.

Moisa Daniela (2011) Pour une anthropologie de la réussite, Martor, 16, pp. 11-16.

Morokvasic Mirjana (1999) La mobilité transnationale comme ressource : le cas des migrants de l'Europe de l'Est, Culture \& Conflits, 33-34, pp. 105-122.

Nedelcu Mihaela (2010) (Re)penser le transnationalisme et l'intégration à l'ère du numérique. Vers un tournant cosmopolitique dans l'étude des migrations internationales ?, Revue Européenne des Migrations Internationales, 26 (2), pp. 33-55.

Noble Greg (2004) Accumulate being, International Journal of Cultural Studies, 7 (2), pp. 233-256.

Olivera Martin (2007) Romanès ou l'intégration traditionnelle des Gabori de Transylvanie, Thèse en ethnologie, Université Paris Ouest-Nanterre La Défense.

Parreñas Rhacel (2001) Mothering from a distance: Emotions, gender, and intergenerational relations in Filipino transnational families, Feminist Studies, 27 (2), pp. 361-390.

Petridou Elia (2001) The taste of home, in Daniel Miller Ed., Home possessions, Oxford, Berg, pp. 87-106.

Portes Alejandro (2001) Introduction: The debates and significance of immigrant transnationalism, Global Networks, 1 (3), pp. 181-193.

Poueyto Jean-Luc (2011) Manouches et mondes de l'écrit, Paris, Karthala, 156 p.

Rapport Nigel and Dawson Andrew (Eds.) (1998) Migrants of identity: Perceptions of home in a world of movements, Oxford, Berg, $224 \mathrm{p}$. 
Riak Akuei Stéphanie (2005) Remittances as unforeseen burdens: The livelihoods and social obligations of Sudanese refugees, Global Migration Perspectives, 18, pp. 2-16.

Rosales Marta (2010) The domestic work of consumption: Materiality, migration and home-making, Ethnographica, 14 (3), pp. 507-525.

Sayad Abdelmalek (1985) Du message oral au message sur cassette : la communication avec I'absent, Actes de la Recherche en Sciences Sociales, 59, pp. 61-73.

Tapia Stéphane (de) (2004) Entre " Nord " et "Sud " : le dynamisme international des transporteurs turcs, Autrepart, 32 (4), pp. 169-186.

Valenzuela Abel, Schweitzer Lisa and Robles Adriele (2005) Camionetas: Informal Travel among Immigrants, Transportation Research Part A, 39, pp. 895-911.

Vertovec Steven (2004) Cheap calls: The social glue of migrant transnationalism, Global Networks, 4 (2), pp. 219-224.

Waldinger Roger (2015) The cross-border connection. Immigrants, emigrants and their homelands, Cambridge, Harvard University Press, 240 p.

Waldinger Roger and Fitzgerald David (2004) Transnationalism in question, American Journal of Sociology, 109 (5), pp. 1177-1195.

Warnier Jean-Pierre (1999) Construire la culture matérielle, Paris, PUF, 176 p.

Wilding Raelene (2006) "Virtual" intimacies? Families communicating across transnational contexts, Global Networks, 6 (2), pp. 125-142. 


\section{Norah Benarrosh-Orsoni}

\section{Phones, Small Talk and Disputes. Transnational Communications and Community Cohesion among Roma Migrants in the Outskirts of Paris}

This paper is an ethnographic exploration of the various roles of phone communications among Romanian Roma migrants in the outskirts of Paris. Speech practices play a fundamental role in their daily sociability and have been deeply transformed since members of this group are scattered throughout Western Europe. Drawing on material culture and consumption studies, this research shows how the contemporary uses of communication tools generate a virtual co-presence among transnational households, and enable migrants to develop a sense of collective ubiquity. After outlining the methodological frame and context of the research, the author analyzes the uses Roma migrants make of their mobile and landline phones, as international communications became a strategic stake in the field of "ethnic business". Then she goes through the details of phone communications and their different aims, insisting on the role of conflicts for both the families and the community.

\section{... Téléphones, petites conversations et disputes. \\ Communications transnationales et cohésion communautaire chez les migrants roms en banlieue parisienne}

Cet article est une exploration ethnographique des divers rôles que jouent les communications téléphoniques chez les migrants roms roumains établis en banlieue parisienne. Les pratiques discursives, qui tiennent un rôle central dans leur sociabilité quotidienne, ont été profondément transformées depuis que les membres de ce groupe sont dispersés entre différents pays d'Europe de I'Ouest. En s'appuyant sur les analyses de la culture matérielle et de la consommation, cette recherche montre comment les usages contemporains des outils de communication produisent une coprésence virtuelle au sein des maisonnées transnationales et permettent aux migrants de développer un sentiment d'ubiquité collective. Après avoir exposé le contexte de cette recherche et la méthodologie adoptée pour la réaliser, I'auteur analyse les usages que les migrants roms font de leurs téléphones portables et fixes, à mesure que les communications internationales sont devenues un enjeu central pour le " commerce ethnique ". Enfin, elle décrit en détail les communications téléphoniques variées et leurs différents propos, en insistant sur le rôle que jouent les conflits tant à l'échelle familiale que communautaire.

\section{... Teléfonos, chismes y conflictos. Comunicaciones transnacionales y cohesión comunitaria entre los migrantes roma en los barrios periféricos de París}

Este artículo es una exploración etnográfica de las diferentes funciones que juegan las llamadas telefónicas entre los migrantes roma rumanos establecidos en los barrios periféricos de París. Las prácticas discursivas que tienen un papel central en su sociabilidad cotidiana, se han transformado profundamente desde que los miembros de este grupo se dispersaron entre los diferentes países de Europa del oeste. A partir de un análisis sobre la cultura material y el consumo, esta investigación muestra cómo el uso contemporáneo de las herramientas de comunicación crea una co-presencia virtual dentro de los hogares transnacionales, y permite a los migrantes desarrollar un sentimiento de ubicuidad colectiva. Tras describir el contexto de esta investigación y la metodología adoptada, el autor analiza los usos que los migrantes Roma hacen de sus teléfonos móviles y teléfonos fijos, mientras las llamadas internacionales se han convertido en un tema central para el "comercio étnico». Por último, describe de manera detallada las comunicaciones telefónicas y sus contenidos, insistiendo sobre la importancia de los conflictos, tanto al nivel familiar como comunitario. 